\title{
98. Leberresektion bei Metastasen: Ergebnisse
}

\author{
A. Fritsch, J. M. Funovics und A. Priesching \\ I. Chirurgische Universitäts-Klinik Wien, Alser Straße 4, A-1090 Wien
}

\section{Liver Resection of Metastases: Results}

\begin{abstract}
Summary. In 171 liver resections from 1965-198191 patients underwent resection because of liver metastases, mainly because of solitary metastases ( $50 \%$ ), 79 GI-tumors, 12 other tumors. 46 synchronous resections, 15 interval resections, and 30 metachronus resections were performed. The operative mortality rate was found to be $29 \%$, in the period $80 / 81$ only $5.8 \%$. We find a 5 -year-survival rate in liver resection of $13.8 \%$ and $24 \%$ in colorectal metastases. Prognostic advantages were given to metastases of tumors with low grade malignancy, after colorectal tumors and curative classified operations.
\end{abstract}

Key words: Metastases of the liver - Liver resection.

Zusammenfassung. Bei 171 Leberresektionen zwischen 1965 bis 1981 wurden bei 91 Patienten vorwiegend wegen solitärer Tumore $(50 \%)$ Lebermetastasen reseziert (79 GI Tumore, 2 andere Tumore). Es wurden 46 synchrone, 15 Intervallresektionen und 30 metachrone Resektionen durchgeführt bei einer Letalität von $29 \%$. Im Zeitraum 1980/81 sank die Letalität auf 5,8\%. Die 5-Jahres-Überlebensrate aller Leberresektionen beträgt 13,8\%, nach colorectalen Metastasen $24 \%$. Prognostische Vorteile zeigten Metastasen nach höherdifferenzierten Tumoren, nach colorectalen Tumoren und kurativ klassifizierten Eingriffen.

Schliusselwörter: Lebermetastasen - Leberresektion.

Manuskript nicht eingegangen. 